\title{
Study on the on-Farm Pre-natal Nutritional Status of Red Chittagong Cows in Selected Breeding Habitat of Satkania Upazila of Chittagong District of Bangladesh
}

\author{
Md. Asaduzzaman ${ }^{1, *}$, Md. Ruhul Amin², Nathu Ram Sarker ${ }^{1}$, Khan Shahidul Huque ${ }^{1}$ \\ ${ }^{1}$ Bangladesh Livestock Research Institute, Savar, Dhaka, Bangladesh \\ ${ }^{2}$ Department of Animal Science, Bangladesh Agricultural University, Mymensingh, Bangladesh
}

Email address:

shaju_blri@yahoo.com (Md. Asaduzzaman)

*Corresponding author

\section{To cite this article:}

Md. Asaduzzaman, Md. Ruhul Amin, Nathu Ram Sarker, Khan Shahidul Huque. Study on the on-Farm Pre-natal Nutritional Status of Red Chittagong Cows in Selected Breeding Habitat of Satkania Upazila of Chittagong District of Bangladesh. Agriculture, Forestry and Fisheries. Vol. 6, No. 5, 2017, pp. 155-160. doi: 10.11648/j.aff.20170605.12

Received: July 16, 2017; Accepted: August 2, 2017; Published: September 1, 2017

\begin{abstract}
The aim of this study was to investigate the feed and nutrient intake, requirement, nutritional status, productive and reproductive performances of pre-natal Red Chittagong cows (RC) under small-scale farm feeding condition. To achieve the aim, a total of ten farmers were randomly selected. Farmers who had at least one pre-natal RC cow were involved in this study. Ten pre-natal RC cows from each of 10 farmers having six months pregnancy and between 2 and 3 parities were selected. The experiment was carried out in Satkania Upazila of Chittagong district of Bangladesh for a period of three months from April 2010 to June 2010. The owner offered feeds to their cows. Animals were fed in stall. The offered feeds and leftover feeds were weighted and recorded daily. The cows were weighed individually at weekly interval and recorded regularly. The intake of total dry matter (DM), metabolizable energy (ME) and crude protein (CP) were $3.39 \mathrm{~kg}, 27.49 \mathrm{MJ}$ and $279 \mathrm{~g}$ per cow per day, whereas, the DM, ME and CP requirements were $4.89 \mathrm{~kg}, 39.0 \mathrm{MJ}$ and $454 \mathrm{~g}$, per cow per day, respectively. The deficiency of DM, ME and CP were $1.50 \mathrm{~kg}, 12.11 \mathrm{MJ}$ and $189 \mathrm{~g}$, per cow per day, respectively. The total live weight gain of pre-natal RC cows was $14.50 \mathrm{~kg}$. The calf's birth weight was $10.95 \mathrm{~kg}$. The going experiment revealed that the nutritional status of pre-natal Red Chittagong cows was negative balance.
\end{abstract}

Keywords: Pre-natal Red Chittagong Cows, Diet, Intake, Requirement, Nutritional Status, Gain, Birth Weight

\section{Introduction}

The three major Challenges facing the developing world today are the alleviation of poverty, meeting current and future needs and preserve genetic resources to ensure sustainability. Poverty combined with the population pressure, land constraints and lack of appropriate production technologies for intensification are the major causes of environmental degradation in low income developing countries like Bangladesh. One of the greatest challenges in the years ahead will be to produce the amount of food needed to feed a rapidly expanding human population which is predicted to be approximately 1.5 times higher than the present level by the year 2020. Malnutrition affects about half a billion people throughout the world and a further 1.5 billion are undernourished or do not eat a properly balanced diet. Livestock products are crucial in this regard providing food (milk and meat) of high nutritive value.

Insufficient supply of feeds throughout the year in tropical countries is a major limitation to ruminant production where the livestock population is high. This is because the demand of food crop production for human consumption reduces the use of land for grazing and forage production. Under these situations, the supplement diet is needed to offer otherwise the livestock productivity cannot be improved. However, the pre-calving nutrition of the mother cow has many important implications in proper fetal growth, a healthy calf at birth, the resistance of calf to stress and disease and a cow that can milk. Improper feeding and poor managements allow serious nutritional problems to develop a fetus [1]. The pregnant 
animals face two types of stress- firstly during pregnancy its body reserves of nutrients are reduced due to fetal development and secondly, just after the initiation of lactation with the sudden secretion of nutrients into milk. So, during this period they need more nutrients [2, 3].

Bangladesh has one of the highest densities of livestock in the world, 145 large ruminants per $\mathrm{km}^{2}$ [4]. It has 24.5 million cattle including 10.0 million lactating animals of which 3.5 million are crossbred cows [5]. The vast majority of this cattle population is of non-descriptive type, which does not belong any specific breed and termed as indigenous cattle. Among the indigenous cattle, there are about 10,489 heads of pure Red Chittagong cattle (RCC) available in Chittagong district of Bangladesh [6], which represented 12 percent of total cattle population in Chittagong district [7]. The number of RCC per holding in the habitat area varied from 1.68 to 3.54 [8]. However, Red Chittagong cattle is improved and promising indigenous cattle variety (Bos indicus) in Bangladesh for its genetic merit, unique characteristics and milk yield and suitable for small-scale farmer. They are reared under poor quality feeds, unbalanced nutrients, improper feeding and poor husbandry management practice and consequently their performances are declined [9]. Therefore, improvement of performances of this indigenous cow is essential. There is no data on nutritional status of pre-natal Red Chittagong cows in Bangladesh. Over the years no study has yet been done to assess the nutritional status of pre-natal Red Chittagong cows under small-scale farm feeding condition. Therefore, it is urgent to investigate the nutritional status of pre-natal Red Chittagong cows with a view to improvement of pre-natal Red Chittagong cows in Bangladesh. Thus, the present study was undertaken to assess the feed and nutrient intake, requirement and nutritional balance of pre-natal RC cows under small-scale farm feeding condition of Satkania Upazila of Chittagong district of Bangladesh.

\section{Materials and Methods}

\subsection{Selection of Study Area and Duration of Study}

This experiment was carried out under small-scale farm in Satkania Upazila of Chittagong district of Bangladesh for a period of three months from April to June 2010.

\subsection{Selection of Pre-natal Red Chittagong Cows}

The experiment was carried out with ten pre-natal Red Chittagong cows. Farmers who had at least one pre-natal Red Chittagong (RC) cow were involved in this study. A total of ten farmers were randomly selected. The pre-natal RC cows from each of 10 farmers having six months pregnancy and between 2 and 3 parities were selected in this experiment.

\subsection{Housing and Feeding Management Practices}

The pre-natal RC cows were reared by the owners under their own feeding and management practices of farms condition. The cows were kept in separate conventional house. All cows were stall fed and followed stall feeding system. The rice straw and naturally grown grasses were given twice daily, between 06:00 to 07:30 hours in the morning and between 15:30 to $16: 30$ hours in the afternoon. The rice straw supplied first followed by freshly cut naturally grown grasses. The rice bran as concentrate diet (polish and husk) was fed twice a day in the morning and afternoon after feeding of roughages. The weight of roughages and rice bran were taken by using a top loading balance before supplying and recorded regularly. There was accessed of clean fresh drinking water, ad libitum to all the experimental animals.

\subsection{Estimation of Feed and Nutrient Intake}

The feed was weighted daily before supplying. The leftover feeds were also weighted and recorded on the following morning before offering morning feed. The daily feed intake was determined by subtracting the amount of leftover from the amount of feed given on the previous day. The metabolizable energy (ME) and crude protein (CP) was determined from the amount of dry matter (DM) fed in 24 hours. The ME and $\mathrm{CP}$ values were determined by multiplying respective $\mathrm{ME}$ and $\mathrm{CP}$ values of feeds.

\subsection{Calculation of CP Values of Intake Diet}

The calculation of $\mathrm{CP}$ values of intake diet based on ARC [6].

\subsection{Weight Determination of Pre-natal Red Chittagong Cows and Their Calf Birth Weight}

The pre-natal experimental RC cows were weighed individually at weekly interval by using portable digital weighing balance and recorded regularly. The weight of RC cows was performed in morning before feeding. The birth weight of calf was taken immediately after born by using the digital weighing balance and recorded. The placenta was also weighed and recorded.

\subsection{Collection and Chemical Analysis of Feed Samples}

The rice straw, natural grasses and rice bran samples were collected from the study area for chemical analysis. The samples were cut into small pieces for determining DM content of fresh sample. At the same time, another portion of samples were dried in the sun and then grinded to pass through $40 \mathrm{~mm}$ mesh sieve. After grinding, the samples were kept in the polythene bags, labeled and stored. Dry matters of feeds were determined immediately after collection. The fresh samples were dried at $55^{\circ} \mathrm{C}$ for $72 \mathrm{hrs}$ in a forced drying oven to determine DM content. The sun-dried samples were subjected to chemical analyses for organic matter (OM), crude protein $(\mathrm{CP})$, crude fiber $(\mathrm{CF})$, ether extract (EE), Ash and nitrogen free extract (NFE) following the procedure AOAC [11]. The metabolizable energy (ME) was determined by using the in-vitro gas production techniques [12]. All the samples were analyzed in duplicate and mean values were recorded. 


\subsection{Nutrient Requirements of Pre-natal Red Chittagong Cows}

The daily dry matter (DM), metabolizable energy (ME) and crude protein $(\mathrm{CP})$ requirements of post-natal RC cows were calculated based on ARC [10].

\subsection{Data Collection and Statistical Analysis}

A formatted register was supplied to the farmers for keeping record. The data on daily feed intake, weekly live weight, date of service, date of calving, calf birth weight and placenta weight were recorded and collected for statistical analysis. The data were analyzed by using the Microsoft Office Excel Worksheet 2007. Mean values and standard error difference were calculated.

\section{Results and Discussion}

\subsection{Chemical Composition of Feeds}

The nutrient composition of feeds fed to pre-natal Red Chittagong cows are shown in Table 1. Nutritive values of feed staffs are determined by the chemical composition. The chemical composition does not give the values of total available nutrient in a feed rather than provides information of nutrient concentration. However, the chemical composition depends on ambient temperature, day length, humidity, rainfall and moisture content of soil. In the current study, farmers offered rice straw, natural grasses and rice bran (Husk plus polish) as a concentrate diet to their pre-natal $\mathrm{RC}$ cows. The DM content of rice straw was lower than the findings of [13] and [14]. The OM content of the same rice straw was higher than the values reported by [15]. The CP content of rice straw was lower than the findings of $[15,16$, 17 and 18], respectively. The CF content of rice straw was higher than the findings of [18]. The EE, Ash and NFE contents of rice straw were almost similar to the observation of [17]. The ME content of rice straw was lower than the findings of $[16,17]$. The variation of chemical composition of rice straw may be due to ambient temperature, day length, humidity, rainfall and moisture content of soil, season and location. The DM content of natural grasses in the present study was lower than the values reported by $[19,20,21,22$, 23 and 24], respectively. The OM and CP content of natural grasses was found similar with the findings of $[20,24]$. The $\mathrm{CP}$ content of the same natural grasses was less similar to that reported by [19]. The CF content of natural grasses was almost similar with the findings of [21]. The EE, Ash and NFE content of natural grasses were more or less similar with the findings of $[19,21,22,23]$, respectively. The ME content of same natural grasses was almost similar with the findings of [14]. The variation of DM, ME and CP content of natural grasses may be due to water content of natural grasses, varieties, stage of maturity, part of the plant, rapid growth of grasses, location and season of year. The DM content of rice bran was similar with the findings of [14]. The OM content of same rice bran was higher than the findings of Islam [25]. The CP content of rice bran was lower than the findings of [14]. The variation of CP content of rice bran may be due to nutrient availability in soil, $\mathrm{N}$ fertilizer application to the soil and husk content. The CF, Ash and EE content of rice bran was more or less similar to the values reported by Islam [25]. The ME content of rice bran was found similar with the findings of [14].

Table 1. Chemical composition of feeds fed to pre-natal Red Chittagong cows.

\begin{tabular}{|c|c|c|c|c|c|c|c|c|}
\hline \multirow{2}{*}{ Name of feed } & \multirow{2}{*}{ DM (g/100g sample) } & \multicolumn{6}{|c|}{ Chemical composition (g/100g DM) } & \multirow{2}{*}{ ME (MJ/kg DM) } \\
\hline & & $\mathbf{O M}$ & $\mathbf{C P}$ & $\mathbf{C F}$ & $\mathbf{E E}$ & Ash & NFE & \\
\hline Rice straw & 87.50 & 86.80 & 3.50 & 51.23 & 1.92 & 13.13 & 45.70 & 5.38 \\
\hline Natural grasses & 16.00 & 91.07 & 11.67 & 37.50 & 1.60 & 8.90 & 54.60 & 7.29 \\
\hline Rice bran & 88.71 & 93.33 & 6.90 & 36.84 & 3.47 & 6.67 & 34.80 & 10.73 \\
\hline
\end{tabular}

$\mathrm{DM}=$ Dry matter; $\mathrm{OM}=$ Organic matter; $\mathrm{CP}=$ Crude protein; $\mathrm{CF}=$ Crude fiber; $\mathrm{EE}=$ Ether extract; $\mathrm{A}=\mathrm{Ash} ; \mathrm{NFE}=\mathrm{Nitrogen}$ free extract; $\mathrm{ME}=$ metabolizable energy; $\mathrm{MJ}=$ Mega joule.

\subsection{Feed and Nutrient Intake of Pre-natal Red Chittagong Cows}

The feed and nutrient intake of pre-natal $\mathrm{RC}$ cows is presented in Table 2. In ruminants, feed intake is influenced by energy and crude protein content of diet, bulk of the feed, quality of forage, vitamin and mineral presence of diet, physical and chemical structure of cellulose with lignin, rate of passage, physiological condition of the animal, level of feeding, frequency of feeding, concentrate to roughage ratios, appetite, water content of feed, rumen and body size, age and breed [26, 27]. The feed intake is also affected by the ambient temperature, humidity and rainfall. The dry matter (DM) intake of rice straw, natural grasses and rice bran was $0.73,1.45$ and $1.21, \mathrm{~kg}$ per day, respectively. Thus the total DM intake was $3.39 \mathrm{~kg}$ per cow per day. The daily total DM intake was lower than the findings of Islam [25].

The DM intake of rice straw, natural grasses and rice bran was lower than the findings of [14], who observed that the average daily DM intake of rice straw, green forage and concentrate of crossbred dairy cows were 3.34, 1.17 and 5.80 $\mathrm{kg}$, respectively. Yasmin [9] observed that the daily DM intake of RC cows ranged from 5.60 to $7.88 \mathrm{~kg}$, which was higher than the present study. The variation of DM intake may be due to availability of feeds, ability, knowledge of feeding, season, location, breed, body size, feeding management practice, animal weight, body condition, stage of production, environmental conditions, forage quality, amount and type of feed offered. The daily total ME and CP intake was $27.49 \mathrm{MJ}$ and $279 \mathrm{~g}$, per cow, respectively. The $\mathrm{ME}$ and $\mathrm{CP}$ intake in the present study was lower than the findings of Islam [25]. Ahmed [14] observed that ME intake 
was ranged from 75.24 to $83.45 \mathrm{MJ}$ per day, which was higher than the findings of the current study. Sharma et al. [28] reported that the $\mathrm{CP}$ intake of dairy buffaloes is $706 \mathrm{~g}$ per day. The variation of ME and $\mathrm{CP}$ intake may be due to feeding, management and breed.

Table 2. Feed and nutrient intake of pre-natal Red Chittagong cows.

\begin{tabular}{|c|c|c|}
\hline Parameters & Mean $(n=10)$ & \pm SED \\
\hline DM intake of rice straw ( $\mathrm{kg} /$ day $)$ & 0.73 & 0.06 \\
\hline DM intake of natural grasses ( $\mathrm{kg} /$ day) & 1.45 & 0.03 \\
\hline DM intake of rice bran (kg/day) & 1.21 & 0.05 \\
\hline Total DM intake (kg/day) & 3.39 & 0.07 \\
\hline Total DM intake ( $\mathrm{kg} / 100 \mathrm{~kg}$ live weight) & 1.79 & 0.03 \\
\hline Total DM intake (g/ kg W ${ }^{0.75} /$ day) & 66.58 & 0.79 \\
\hline Total ME intake (MJ/ $\mathrm{kg} \mathrm{W}^{0.75} /$ day) & 0.54 & 0.01 \\
\hline Total CP intake ( $\mathrm{g} /$ day) & 279 & 9.43 \\
\hline Total CP intake ( $\mathrm{g} / \mathrm{kg} \mathrm{W}^{0.75} /$ day) & 5.48 & 0.02 \\
\hline $\mathrm{M} / \mathrm{D}$ values of intake diet (ME, MJ/kg DM) & 8.10 & 0.03 \\
\hline $\mathrm{CP}$ values of intake diet (g/kg DM) & 82 & 0.10 \\
\hline
\end{tabular}

$\mathrm{n}=$ number of cows; SED = Standard error difference; $\mathrm{DM}=$ Dry matter; $\mathrm{ME}=$ Metabolizable energy; $\mathrm{M} / \mathrm{D}=$ Energy concentration of intake diet dry matter; $\mathrm{CP}=$ Crude protein concentration of diet dry matter.

\subsection{Present Nutritional Status, Requirement and Nutrient Balance of Pre-natal Red Chittagong Cows}

The present nutritional status, requirement and nutrient balance of pre-natal RC cows are depicted in Table 3. Nutritional status indicates the balanced diet, as required by the animals, is being provided or not. The relationship between a cow's diet and the stage of pregnancy is a fundamental consideration to the management of dairy cows. The daily requirement of DM, ME and $\mathrm{CP}$ of pre-natal $\mathrm{RC}$ cows was $4.49 \mathrm{~kg}, 39.58 \mathrm{MJ}$ and $468 \mathrm{~g}$, respectively. The $\mathrm{M} / \mathrm{D}$ and $\mathrm{CP}$ values of required diet were $11.68 \mathrm{MJ}$ and $138 \mathrm{~g}$ per kg DM, respectively. The DM requirement of pre-natal $\mathrm{RC}$ cows in the present study was lower than the [10]. According to ARC [10], the DM requirement of pregnant "standard" cows is $3.0 \mathrm{~kg}$ per $100 \mathrm{~kg}$ live weight per day. Animals require energy for maintenance of essential life process of blood circulation, respiration, muscular activities, digestion and movement of themselves. Energy requirement of cattle is depended on live weight, growth rate and rate of productivity of the animals. Energy expended for the maintenance of an animal is converted into heat and leaves the body in this form. The ME requirement of pre-natal RC cows in the present study was lower than the [10]. According to ARC [10], the ME requirement of pregnant "standard" cows is $42.90 \mathrm{MJ}$ per day per cow. The $\mathrm{CP}$ requirement of pre-natal $\mathrm{RC}$ cows in the present study was also lower than the [10]. The CP requirement of pregnant "standard" cows is $519 \mathrm{~g}$ per day. The variation of DM, ME and CP requirement of pre-natal RC cows may due to body size and breed. The amount of protein a cow needs depends on animal size, growth and stage of pregnancy. The protein requirement of maintenance is usually assumed to be the sum of endogenous urinary $\mathrm{N}$, metabolic fecal $\mathrm{N}$, and dermal (scruff and hair) $\mathrm{N}$ losses, multiplied by the factor 6.25 [29]. The DM, ME and $\mathrm{CP}$ balance of pre-natal Red Chittagong cows in the present study was found deficit. The findings of the present experiment are in agreement with the findings of [14]. The deficit balance of nutrients in the present experiment may be due to supply of inadequate feeds and imbalanced feeding. It is fact that the required levels of energy and protein may increase the availability of nutrients through intake and digestibility which reflected in the growth rate of cows. The performance is positively related to the nutritional status of cows.

Table 3. Present nutritional status, requirement and nutrient balance of pre-natal Red Chittagong cows.

\begin{tabular}{|c|c|c|c|}
\hline Parameters & Nutrient intake from farmers diet \pm SED & Nutrient requirement $(A R C, 1995) \pm$ SED & Nutrient balance \\
\hline Total DM (kg/day) & $3.39 \pm 0.07$ & $4.89 \pm 0.15$ & -1.50 \\
\hline Total DM (kg/100kg live weight) & $1.79 \pm 0.03$ & $2.59 \pm 0.07$ & -0.80 \\
\hline Total DM (g/kg W' $0.75 /$ day) & $66 \pm 0.79$ & $96 \pm 1.87$ & -30 \\
\hline Total ME (MJ/day) & $27.49 \pm 0.30$ & $39.59 \pm 1.27$ & -12.10 \\
\hline Total ME (MJ/kg W0.75/day) & $0.54 \pm 0.05$ & $0.78 \pm 0.01$ & -0.24 \\
\hline Total CP (g/day) & $279 \pm 9.43$ & $468 \pm 16.01$ & -189 \\
\hline Total CP (g/kg W ${ }^{0.75} /$ day) & $5.48 \pm 0.02$ & $9.19 \pm 0.19$ & -3.71 \\
\hline $\mathrm{CP}$ values (g/kg DM) & $82 \pm 0.10$ & $138 \pm 0.54$ & -56 \\
\hline
\end{tabular}

$\mathrm{SED}=$ Standard error difference; $\mathrm{DM}=$ Dry matter; $\mathrm{ME}=$ Metabolizable energy; $\mathrm{M} / \mathrm{D}=$ Energy concentration of diet dry matter; $\mathrm{CP}=\mathrm{Crude}$ protein concentration of diet dry matter. 


\subsection{Productive and Reproductive Performances of Pre-natal Red Chittagong Cows}

The productive and reproductive performance of pre-natal $\mathrm{RC}$ cows is shown in Table 4. The initial live weight of prenatal RC cows was $181.50 \mathrm{~kg}$ and the final live weight after three months of experiment was $196.0 \mathrm{~kg}$. The total live weight gain before calving was $14.50 \mathrm{~kg}$. Thus, the growth rate of cows was $161 \mathrm{~g}$ per day. The growth rate of RC heifer is $190 \mathrm{~g}$ per day that reported by [30]. In the present study, the live weight gain of cows may be due to development of foetus. The foetus makes $70 \%$ of its growth during the last three months of pregnancy that reported by [6]. The birth weight of RC calves was $10.95 \mathrm{~kg}$. The birth weight of calves is an important feature as because calves with heavier birth weight have a higher average post-natal survival rate if the calves born without exercise problems and have a superior subsequent growth. It depends on the nutrition and health status of cows. In the present experiment, the birth weight of $\mathrm{RC}$ calves was lower than the findings of $[24,30,31,32$ and 33], respectively. The variation in birth weight is partly genetic but largely due to environment especially nutrition management and health that reported by [27]. The lower birth weight of RC calves might be due to effect of deficit nutrient of pregnant cows during the pregnancy period. The placenta weight was $2.96 \mathrm{~kg}$ and calf with placenta weight was 13.91 $\mathrm{kg}$. The calf with placenta weight in the present experiment is almost similar to the total live weight gain $(14.50 \mathrm{~kg})$ of prenatal RC cows before calving. Therefore, it can be said that the live weight gain of pre-natal RC cows might be due to growth of foetus but not original growth of cows.

The gestation begins with fertilization and terminals the birth of a limiting animal [34]. It is one of the indicators of productivity performance of a dairy cow. The gestation length of $\mathrm{RC}$ cows in the present study was found higher to the findings of [35], who reported that the gestation length of $\mathrm{RC}$ cows in rural conditions was 282 days. Habib et al. [30], reported that the gestation period of RC cows was 287.0 days, which was slightly higher than the findings of the present study. Bhuiyan et al. [8], reported the gestation length of RC cows was 283.69 days which was closed to the present findings. The variation of gestation length may be due to the feeding management practices, location and environment.

Table 4. Productive and reproductive performances of pre-natal RC cows.

\begin{tabular}{lll}
\hline Parameter & Mean $(\mathbf{n}=\mathbf{1 0})$ & 土 SED \\
\hline Initial live weight $(\mathrm{kg})$ & 181.50 & 10.89 \\
Final live weight $(\mathrm{kg})$ & 196.0 & 10.63 \\
Average live weight $(\mathrm{kg})$ & 188.81 & 1.32 \\
Average metabolic live weight $\left(\mathrm{kgW}^{0.75}\right)$ & 50.93 & 0.27 \\
Total live weight gain of cows $(\mathrm{kg})$ & 14.50 & 0.38 \\
Daily live weight gain of cows $(\mathrm{g})$ & 161 & 4.22 \\
Birth weight of calves $(\mathrm{kg})$ & 10.95 & 0.30 \\
Placenta weight $(\mathrm{kg})$ & 2.96 & 0.14 \\
Calf plus placenta weight $(\mathrm{kg})$ & 13.91 & 0.34 \\
Gestation length (days) & 284.50 & 0.79 \\
\hline
\end{tabular}

$\mathrm{n}=$ Number of cows; SED $=$ Standard error difference

\section{Conclusion}

The feed and nutrient intake of the going experiment gave an idea that the pre-natal nutritional status of Red Chittagong cows was deficit. The pre-natal nutrition of cows affect the live weight gain of cows before calving and calf birth weight. Therefore, it can be concluded that the small-scale farm feeding would be urgently improved to obtain optimum production from pre-natal RC cows.

\section{References}

[1] Ken Ziegler, Management in the last trimester of pregnancy. $\mathrm{Ag}$ - Info Centre, toll-free in Alberta at 310 - FARM (3276), for agricultural information: (C) $2001-2010$ Government of Alberta Copyright and Disclaimer. 2009.

[2] K. H. Lotthammer, Importance of $\beta$-carotene for fertility of dairy cattle. Feedstuff. 1996; 51: 16 - 50.

[3] N. M. Bellido, J. D. Wallace, E. E. Parker and M. D. Finkner, Influence of breed, calving season, supplementation and year on productivity of range cows. J. Anim. Sci. 1981; 52: 455 - 462.

[4] NARS Bangladesh, Agricultural Research Priority: Vision 2030 and beyond. Bangladesh Agricultural Research Council, Farmgate, Dhaka. 2010.

[5] Anon, High-value Agriculture in Bangladesh: An Assessment of Agri-business Opportunities and Constraints. World Bank Report, Bangladesh Development Series. 2008; 21.

[6] M. M. Hossain, A. K. F. H. Bhuiyan, M. O. Faruque and G. K. Dev, Characterization and distribution pattern of Red Chittagong cattle of Bangladesh. Progress Agriculture. 2006; 17: 103 - 110.

[7] M. P. Mostari, K. S. Huque, M. S. Hasnath and Z. Gulshen, Productive and reproductive efficiency of Red Chittagong cattle under farm condition. Progressive Agriculture. 2007; 18: 109 - 114 .

[8] A. K. F. H. Bhuiyan, M. Shahjalal, M. N. Islam, A. K. M. A. Rahman, J. F. Keown, L. D. Van Vleck, R. W. Blake, S. S. Islam, A. Ashraf and M. Alam, Characterization, conservation and improvement of Red Chittagong cattle of Bangladesh. Bangladesh Journal of Progressive Science and Technology. 2007; 5: $26-28$.

[9] M. F. Yasmin, Effect of supplementing concentrate on intake, digestibility, milk yield and composition of Red Chittagong cows fed Urea Molasses straw based diet, MS Thesis, Department of Animal Nutrition, Bangladesh Agricultural University, Mymensingh. 2006.

[10] ARC (Agricultural Research Council). The Nutrient Requirements of Ruminant Livestock. CAB International, Wallingford, United Kingdom. 1995. pp. 73 -310.

[11] AOAC (Association of Official Agricultural Chemists). Official Methods of Analysis. $17^{\text {th }}$ edition. AOAC, Washington D. C. 2003.

[12] K. H. L. Menke, L. Raab, A. Salewaskki, H. Steingass, D. Fritz and W. Schnerider, The estimation of digestibility and metabolizable energy content of ruminant feedstuffs from the gas production when they are incubated with rumen liquor in vitro. Journal of Agricultural Science. 1979; 93: 217 - 222. 
[13] B. V. Chinh and L. Viet Ly, Protein of agro-byproducts as feed resources for buffaloes in Vietnam: Buffalo Workshop. 2001. Accessed 17-18 December 2001.

http://www.mekarn.org/procbuf/chin.htm

[14] T. U. Ahmed, Studies on nutritional status of dairy cows of Bangladesh and improvement of their productive and reproductive performance in Baghabarighat area through nutritional manipulation, $\mathrm{PhD}$ Thesis, Department of Animal Nutrition, Bangladesh Agricultural University, Mymensingh. 2006.

[15] G. A. Nader and P. H. Robinson, Effects of maceration of rice straw on voluntary intake and performance of growing beef cattle fed rice straw-based rations. Animal Feed Science and Technology. 2008; 146: 74 - 86.

[16] D. Kiran and U. Krishnamoorthy, Rumen fermentation and microbial biomass synthesis indices of tropical feedstuffs determination by the in vitro gas production technique. Animal Feed Science and Technology. 2007; 134: 170 - 179.

[17] A. Bhuiyan, M. A. Akbar and M. E. Hossain, Nutritive value of damp rice straw and its feeding effect on aflatoxin transmission into cow's milk. Pakistan Journal of Nutrition. 2003; $2: 153-158$

[18] D. Floulkes, Rice straw as a livestock feed. Agnote. 1998; 22: $273-275$.

[19] S. K. Ranjhan and R. C. Katiyar, Chemical Composition and nutrition value of Makra (Daetylocteniom egiptiumlin) and indigenous monsoon grass. Indian Journal of Dairy Science. 1969; 22: 92 - 94.

[20] M. R. Alam, Potential use legume tree leaves as forage in Bangladesh. Winrock International (JN Daneol and JM Roshetok), Nitrogen fixing trees for fodder production. United State of America. 1990; 205 - 211.

[21] S. N. Mahatab, A. Ali and A. H. M. Asaduzzaman, Average chemical composition and nutritive value of livestock feeds. Animal Nutrition Section, Livestock Research Section, Mohakhali, Dhaka. 1987; 124 - 13.

[22] M. A. H. Sarker, Studies on feed energy requirement of sheep offered two forages. MS Thesis, Department of General Animal Science, Bangladesh Agricultural University, Mymensingh. 1990.

[23] M. M. Rahman, M. R. Islam, M. M. Rahman and M. A. Zaman, Study on the livestock feeds and fodder and feeding practices in Bangladesh and their nutritive evaluation. Bangladesh Livestock Research Institute, Savar, Dhaka. 1991.

[24] M. R. Alam, M. A. Akbar and M. R. Amin, Production potentials of goats and nutritive value of the foodstuffs fed to goat. Bangladesh Agricultural University, Mymensingh. 1992; $173-177$.

[25] S. S. Islam, Development of feeding system for improving productive performance of Red Chittagong cattle of Bangladesh. PhD Thesis, Department of Animal Nutrition, Bangladesh Agricultural University, Mymensingh. 2010.

[26] T. N. Edey, Sheep and Goat Nutrition: A course manual in tropical sheep and goat production. Australian Universities, International Development Program, Canberra. 1983; 29 - 96.

[27] C. Devendra and M. Burns, Goat production in the Tropics. Commonwealth Agriculture Bureaux, Farnham House, Farnham Royal, United Kingdom. 1983.

[28] K. Sharma, N. Dutta and U. Naulia, An on-farm appraisal of feeding urea - treated straw to buffaloes during late pregnancy and lactation in a mixed farming system. Livestock Research for Rural Development. 2004; 16: 1 - 10.

[29] Chizzotti ML, Tedeschi LO, Valadarsres Filho SC. A metaanalysis of energy and protein requirements for maintenance and growth of Nellore cattle. Journal of Animal Science. 2008; 86: 1588 - 1597 .

[30] M. A. Habib, A. K. F. H. Bhuiyan, M. S. A. Bhuiyan and A. A. Khan, Performance of Red Chittagong Cattle in Bangladesh Agricultural University Dairy Farm. Bangladesh Journal of Animal Science. 2003; 32: $101-108$.

[31] M. Alam, A. K. F. H. Bhuiyan, A. Ali and A. Mamun, Genetic analysis of birth weight and milk production of Red Chittagong cattle of Bangladesh. Bangladesh Journal of Animal Science. 2007; 36: 24 - 32.

[32] A. K. F. H. Bhuiyan, M. M. Hossain and G. K. Deb, Indigenous cattle genetic resources of Bangladesh and a way of forward to their development. Bangladesh Journal of Progressive Science and Technology. 2007a; 5: 105-112.

[33] S. Akhter, K. S. Huque, M. A. Jalil and M. R. G. Islam, Conservation, selection and improvement of Red Chittagong cattle selective breeding, feeding and management. Bangladesh Livestock Research Institute, Savar, Dhaka. 10-11 June 2004.

[34] G. W. Salisbury and L. N. Vandemark, Physiology of Reproduction and Artificial Insemination of cattle. WH Freeman and company (Editors), USA. 1961.

[35] M. K. I. Khan, K. S. Huque, A. G. Miah and M. J. Khatun, Study on the performances of Red Chittagong cows under different production system. Pakistan Journal of Biological Science. 2000; 3: 318 - 319 . 